\title{
The Drone Sector in Europe
}

\author{
Blanca de Miguel Molina and Marival Segarra Oña
}

\begin{abstract}
The aim of this chapter is to review the industry sector in Europe, which involves big companies as well as SMEs. The leading European countries, the main competitors, and the main competitive advantages of the industry are analysed. We have identified five different segments in which companies compete based on distinctive features (toys, hobby/leisure, professional, commercial, and military). The homogenization of the industry, especially in the toy, hobby, and commercial subsectors, is mainly led by big companies, which at the same time also represent the largest market share. We have concluded that there are no entry barriers besides technology and commercial distribution, but the main difficulty that is hampering the industry's expansion is regulation. This affects in particular the hobby/leisure and commercial drone segments, some areas more than others; while agricultural and military drones are expanding and evolving rapidly, professional filming and photography and toys are still too dependent on safety or legal issues, such as privacy concerns. It is also remarkable that companies from China and the USA are reaching the top positions. This should be taken into consideration by European policy makers, as the decisions made in the next years will be the key to the development of the sector in Europe.
\end{abstract}

\section{Introduction}

Why is it important to analyse the drone market first? There are two main reasons. Firstly, it illustrates the potential of this steadily growing market, which, due to the lack of unification of national laws in a common European regulation, is not fully exploited. Secondly, it shows why it is so difficult to reach a common agreement:

B. de Miguel Molina $(\bowtie) \cdot$ M. Segarra Oña

Department of Management, Universitat Politècnica de València, Valencia, Spain

e-mail: bdemigu@omp.upv.es

(C) The Author(s) 2018

M. de Miguel Molina and V. Santamarina Campos (eds.), Ethics and Civil Drones,

SpringerBriefs in Law, https://doi.org/10.1007/978-3-319-71087-7_2 
tens of drone application and thus drone characteristics (e.g., size, weight, engine power, range of the aircraft, etc.) exist. Thus, before regulating markets (drones), first the market has to be described and analysed in detail to find a proper solution that pleases all: industry, governments, the military, researchers, and the general public.

How can we define the drone industry? This question needs to be answered to structure the information, since up to now information regarding drones has not been easy to find. This might be because the regulations do not fully support their use, because military uses are still the most common ones and the army industry treats everything as strictly secret, because technology is developing so fast that sharing information would help competitors, or because the rise of the industry is so fast that there is no time to analyse data and research the insights or to disseminate news.

Although difficulties exist, we will retrieve information regarding the drone industry and restructure it to try to provide readers with an engaging chapter that helps them to understand the main facts, characteristics, and strategic opportunities that the industry currently offers.

The Cambridge English Dictionary offers two definitions of a drone:

- an aircraft that does not have a pilot but is controlled by someone on the ground and is used especially for dropping bombs or for surveillance (meaning careful watching of a place);

- an aircraft without a pilot that is controlled by someone on the ground and is used especially as a hobby.

These definitions are very useful, as they clarify not only the meaning but also the main uses of drones. In the second definition, we could include different uses that have recently appeared, such as safety purposes, transport and delivery, and so on. As there is no unique word to name an aircraft without a pilot, it is also quite usual to find the following definitions:

UAV (Unmanned Aerial Vehicle)

UAS (Unmanned Aerial System)

UCAV (Unmanned Combat Aerial Vehicle)

RPA (Remotely Piloted Aircraft)

RPAS (Remotely Piloted Aircraft System).

Drone and UAV/UAS are commonly used to refer to military uses and RPA/ RPAS to name drones with civilian purposes.

Although drones seem to be a very modern invention and there is no consensus regarding the first use of a drone, it seems that drones started to be used for military purposes. The first patent for a "Method of and apparatus for controlling mechanism of moving vessels or vehicles" was filed by Nikola Tesla in 1898 (Infographic 2016), although it was in 1951 that the first prototypes of Ryan's Q-2C Firebee 
pilotless aircraft were tested. Designed by the company Ryan Aeronautical as a target contract from the North American Air Force, this drone was in production for over 40 years and is still being used by some military organizations (San Diego Air and Space Museum 2017).

Nowadays, different patents are being filed that are as specific as drones without propellers (application number KR20150177849 20151214) or drones capable of operating in an aqueous environment (application number US201614994662 20160113), showing how interesting the industry can be for new companies and new business ideas.

\section{Overview of the Drone Sector}

The use of drones has been growing during the last years, and the two main market segments (military and hobby/leisure) have turned into three, depending on their final uses: military, commercial, and hobby. Figure 1 presents the estimated evolution of the three segments. Although the military segment is the main market by value, the figure indicates that the other two segments will expand during the next years.

Although the use of drones has generated considerable controversy due to privacy and safety awareness, nowadays people's perceptions about "good" uses of drones related to civil uses (commercial and hobby) have changed their image and acceptance (Table 1). Among the accepted uses of unmanned aerial vehicles, we may cite those related to health (transport of blood and defibrillators), humanitarian

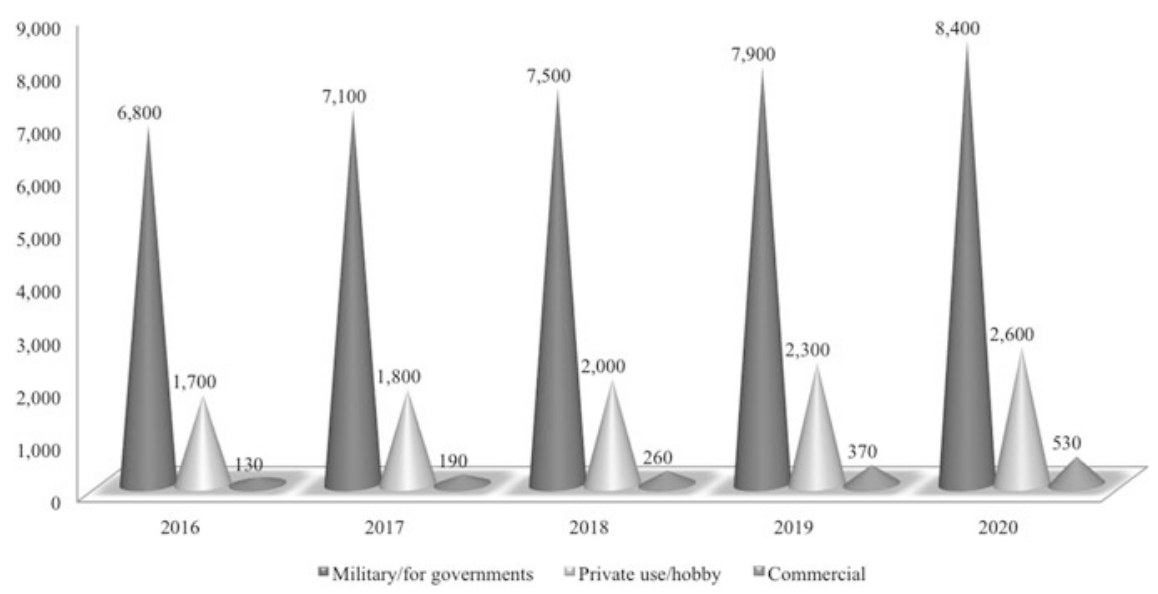

Fig. 1 Estimated value of drone market segments worldwide, 2016-2010 (mill. US\$). Source Own elaboration from data of Moe et al. (2016) 
Table 1 Acceptable drone applications

\begin{tabular}{l|l}
\hline Accepted uses & \\
\hline Source & Use \\
\hline Amukele et al. (2017) & Blood transportation \\
\hline Hardy et al. (2017) & Mapping malaria vector habitats \\
\hline Pulver et al. (2016) & Transporting automated external defibrillators \\
\hline Chabot and Francis (2016) & Bird detection \\
\hline Hodgson et al. (2017) & Surveying marine fauna \\
\hline Sankey et al. (2017) & Forest monitoring \\
\hline Casella et al. (2017) & Mapping coral reefs \\
\hline Szantol et al. (2017) & Mapping orangutan habitat \\
\hline Chowdhury et al. (2017) & Disaster response and relief \\
\hline Restas (2015) & Supporting disaster management (earthquakes, floods, fires) \\
\hline
\end{tabular}

Source Own elaboration from different sources

actions (drones for social goods and humanitarian purposes), shipping products to customers (Amazon's fleet of drones), or ecological applications (surveying fauna and forest monitoring), among others.

However, not only are the applications of drones evolving; the expected revenue increase in the next 10 years is also impressive. According to Tractica (2017c), the greatest evolution will take place in North America, Asia, and Europe, which are also the areas of the market leaders nowadays.

The industry is growing fast, driven mainly by technology. The number of drone-specific exhibitions and conferences is rising (for instance UAV Expo in Brussels or AUVSI's Xponential in the USA), and rapid industry developments are evident. Some examples are drones with robotic arms that can grab objects and magnetic pieces containing drone engines that can be adjusted to objects and turn them into drones (prototypes by Prodrone, a Japanese company). Additionally, though, safety and research are leading the change, and interesting conclusions are being drawn; indeed, the British company Consortiq's CQNet, by collecting and analysing data, defines landing with minimal battery charge as the main reason for the lack of drone safety. The possibilities of the industry are immense, and currently the regulatory barrier (Pauner et al. 2015) seems to be the main impediment to the drone industry taking off definitively (Fig. 2).

Regarding manufacturers, China's DJI followed by the French Parrot occupy the top positions, according to Droneii (2016a), followed by Chinese and North American companies, as reflected in Fig. 3. 


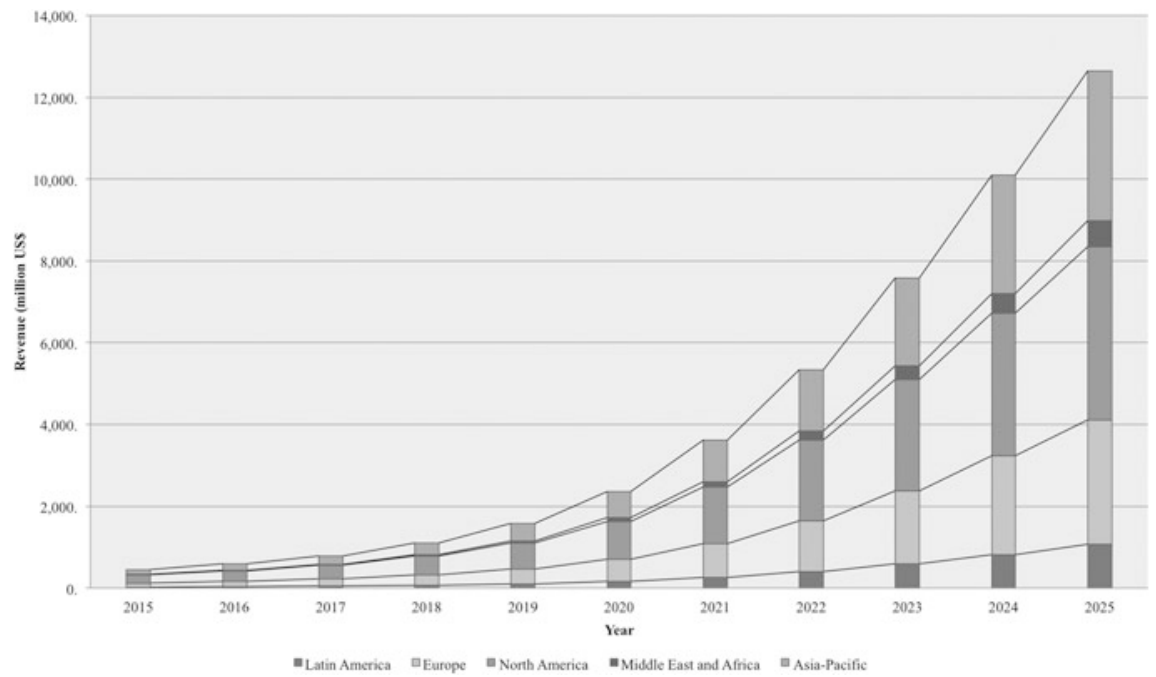

Fig. 2 Projected commercial drone revenue from 2015 to 2025 (in million US dollars). Source Own elaboration from data of Tractica $(2017 \mathrm{c})$

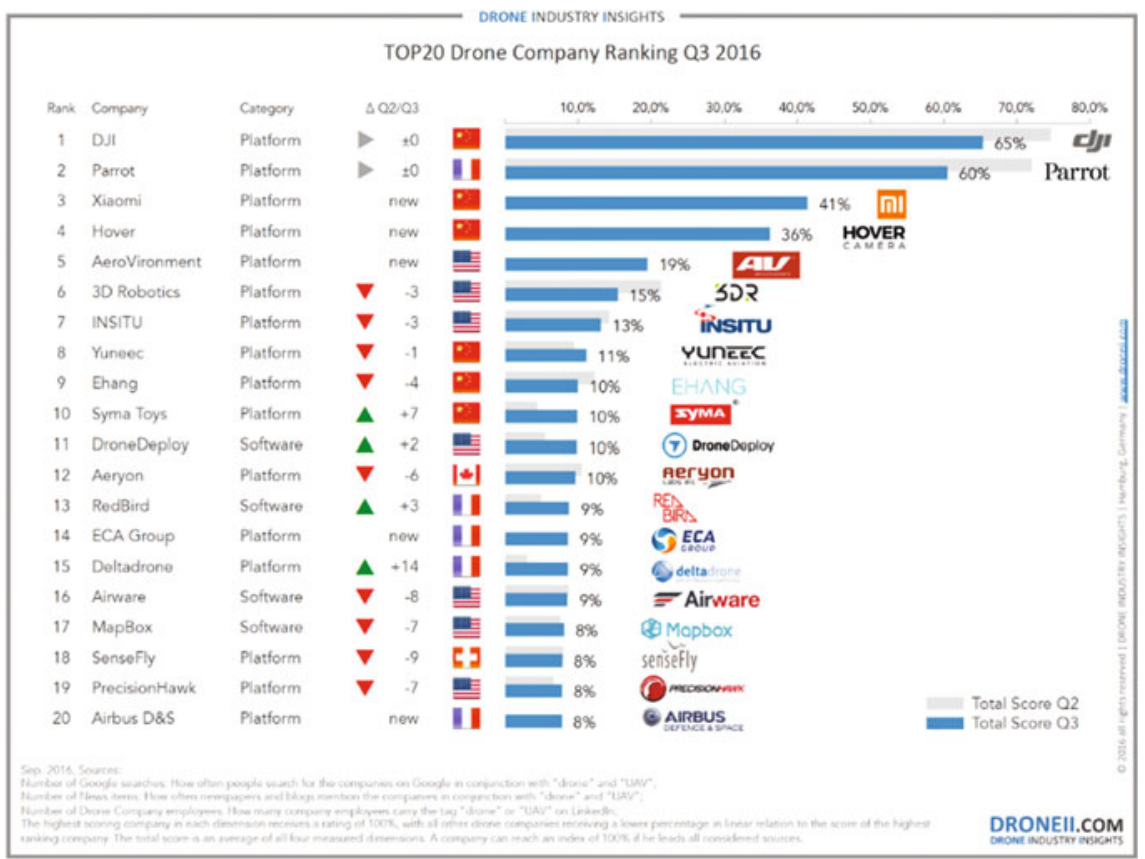

Fig. 3 Drone company ranking, Q3 2016 (Droneii 2016a), with permission of the company (https://www.droneii.com/top20-drone-company-ranking-q3-2016) 


\section{Market Segments}

Segmentation is a market strategy focused on the consumer side, which allows a better fit between products and users' requirements (Smith 1956). A firm that follows a market segmentation strategy is expected to increase its profitability (Wind 1978), although an empirical study is needed. In this study the basic demographic data, such as customer characteristics, users' needs, final use, and so on, are necessary to determine the different existing segments. This goal of this study is to identify and classify the market segments or "sets of buyers" that indeed will be the industry's target groups and will define companies' marketing strategies (Venter et al. 2015).

Markets for drones tend to be segmented in relation to their use, which also corresponds to price ranges. Generally, the sector is structured in three groups: military, commercial, and hobby. For our analysis, however, we have divided the market into five groups (Table 2), which we have defined after taking into consideration the theoretical market segmentation background.

Forecasting undertaken for the industry by the Teal Group (2013) and Tractica (2016, 2017a), among others, predicts future growth for all the market segments. For example, concerning the hobby segment, Tractica (2016) indicates that the revenue worldwide amounted to US\$1865.65 million in the year 2015. Moreover, it estimates that the revenue for this segment will be US\$3528.73 million in 2018 and US\$5031.36 million in 2022. In relation to the military segment, the Teal Group (2013) estimates that the production value worldwide will be US\$2629.1 million in 2015, while it will be US\$4075.4 million in 2018 and US\$8076.4 million in 2022.

Table 2 Market segments for drones

\begin{tabular}{l|l|l|l}
\hline Use & Customer target & Price (€) & Example of drones \\
\hline Group 1-Toys & Children & 49.95 & X_DRONE_ATOM_221 \\
\hline Group 2-Hobby & Young people and adults & 179.99 & Cheerson CX 20 \\
\hline Group 3-Professional & $\begin{array}{l}\text { Professionals (for aerial } \\
\text { filming and photography } \\
\text { services) }\end{array}$ & $\begin{array}{l}4875 \\
549\end{array}$ & $\begin{array}{l}\text { DJI Inspire 1 Pro } \\
\text { Parrot BEBOP 2 FPV }\end{array}$ \\
\hline Group 4-Commercial & $\begin{array}{l}\text { Companies in industries such } \\
\text { as agriculture, media, mining, } \\
\text { energy, construction, etc. }\end{array}$ & $\begin{array}{l}19,921.2 \\
10,172.5\end{array}$ & $\begin{array}{l}\text { Altura Zenith } \\
\text { (Aerialtronics) } \\
\text { Alta 6 (Freefly) }\end{array}$ \\
\hline Group 5-Military & Governments & $\begin{array}{l}\text { Not } \\
\text { available }\end{array}$ & RQ-2A Pioneer \\
\hline
\end{tabular}

Sources Teal Group (2013), Tractica (2016, 2017a), and own elaboration through an analysis of the companies in the sector 
The use of drones for commercial purposes in outdoor environments has increased in recent years, and this tendency will continue in the future. Their use for commercial purposes means their use in sectors such as infrastructure, transport, insurance, media and entertainment, telecommunications, agriculture, security, and mining (PwC 2016). Tractica (2017c) indicates that the worldwide revenue for commercial drones was US\$452.43 million in the year 2015 . It estimates that the revenue will be US\$1110.59 million in 2018 and US\$5334.68 million in 2022.

Figure 4 shows that the highest estimated growth in the next years will occur in the commercial segment; that is, companies in other industries will demand more drones for monitoring activities, mapping, and surveying (Narkus-Kramer 2017). In the future more industries will probably find new applications for drones that the current technology does not allow; then drone manufacturers will offer these features in their products (Ott 2012). Movement to the commercial segments can be detected nowadays in companies such as DJI, which has started to partner with other companies to offer drones with software specializing in agriculture, mining, and construction.

Focusing on the European market, Table 3 might explain why companies are interested in the drone industry and are developing specific software for drones. The turnover data show that the highest values are for energy, construction, agriculture, real estate, and transport. However, if we consider turnover by firm, interesting markets for drone manufacturers will be energy, water and waste, postal and courier activities, telecommunication, and mining. All these sectors are currently target markets for drone manufacturers.

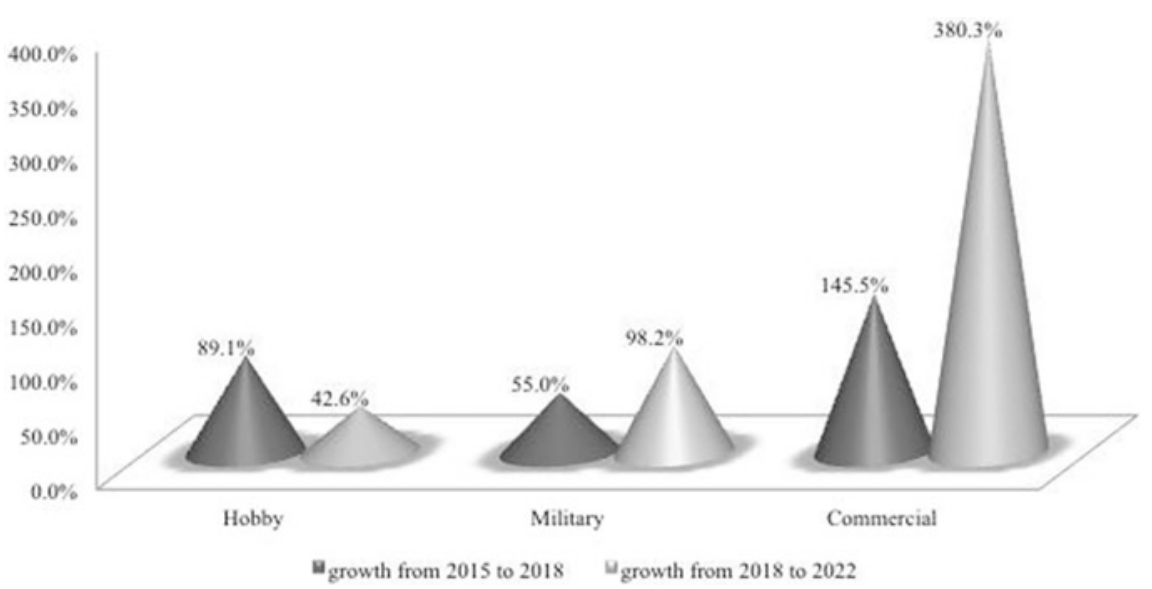

Fig. 4 Estimated growth for segments in the next years. Source Own elaboration from data of the Teal Group (2013) and Tractica (2016, 2017c) 
Table 3 European data related to industries in which outdoor drones can be used (EU 20 countries 2014)

\begin{tabular}{|c|c|c|c|c|}
\hline Sector & $\begin{array}{l}\text { Number of } \\
\text { firms }\end{array}$ & Turnover $^{\mathrm{a}}$ & $\begin{array}{l}\text { Largest } \\
\text { number of } \\
\text { firms }\end{array}$ & $\begin{array}{l}\text { Largest } \\
\text { turnover }\end{array}$ \\
\hline $\begin{array}{l}\text { Electricity, gas, steam, } \\
\text { and air conditioning } \\
\text { supply }\end{array}$ & 87,465 & $1,478,875.8$ & $\begin{array}{l}\text { France, Spain, } \\
\text { Italy, Czech } \\
\text { Republic }\end{array}$ & $\begin{array}{l}\text { Germany, } \\
\text { Italy, United } \\
\text { Kingdom, } \\
\text { France }\end{array}$ \\
\hline $\begin{array}{l}\text { Water supply; sewerage, } \\
\text { waste management, and } \\
\text { remediation activities }\end{array}$ & 75,738 & $253,000.0$ & $\begin{array}{l}\text { France, Italy, } \\
\text { Poland }\end{array}$ & $\begin{array}{l}\text { Germany, } \\
\text { United } \\
\text { Kingdom, } \\
\text { France, Italy }\end{array}$ \\
\hline Construction & $3,441,304$ & $1,577,430.1$ & $\begin{array}{l}\text { France, Italy, } \\
\text { Spain, } \\
\text { Germany, } \\
\text { United } \\
\text { Kingdom }\end{array}$ & $\begin{array}{l}\text { France, } \\
\text { United } \\
\text { Kingdom, } \\
\text { Germany, } \\
\text { Italy } \\
\end{array}$ \\
\hline $\begin{array}{l}\text { Land transport and } \\
\text { transport via pipelines }\end{array}$ & 916,520 & $530,000.0$ & $\begin{array}{l}\text { Spain, Poland, } \\
\text { Italy, France }\end{array}$ & $\begin{array}{l}\text { Germany, } \\
\text { France, } \\
\text { United } \\
\text { Kingdom, } \\
\text { Italy } \\
\end{array}$ \\
\hline $\begin{array}{l}\text { Postal and courier } \\
\text { activities }\end{array}$ & 65,800 & $110,000.0$ & $\begin{array}{l}\text { United } \\
\text { Kingdom, } \\
\text { Germany, } \\
\text { Netherlands, } \\
\text { Spain } \\
\end{array}$ & $\begin{array}{l}\text { Germany, } \\
\text { United } \\
\text { Kingdom, } \\
\text { France }\end{array}$ \\
\hline Insurance & n.a. & n.a. & $\begin{array}{l}\text { Germany, } \\
\text { France, Spain }\end{array}$ & $\begin{array}{l}\text { Germany, } \\
\text { France, Italy }\end{array}$ \\
\hline $\begin{array}{l}\text { Motion picture, video, } \\
\text { and TV programme } \\
\text { production; sound } \\
\text { recording and music } \\
\text { publishing activities }\end{array}$ & 138,246 & $70,573.2$ & $\begin{array}{l}\text { France, United } \\
\text { Kingdom, } \\
\text { Netherlands, } \\
\text { Sweden, } \\
\text { Germany } \\
\end{array}$ & $\begin{array}{l}\text { United } \\
\text { Kingdom, } \\
\text { France, } \\
\text { Germany }\end{array}$ \\
\hline $\begin{array}{l}\text { Advertising and market } \\
\text { research }\end{array}$ & 300,440 & $160,000.0$ & $\begin{array}{l}\text { Netherlands, } \\
\text { Germany, } \\
\text { France, Spain }\end{array}$ & \begin{tabular}{|l|} 
United \\
Kingdom, \\
Germany, \\
France \\
\end{tabular} \\
\hline Telecommunication & 45,377 & $378,000.0$ & $\begin{array}{l}\text { United } \\
\text { Kingdom, } \\
\text { Poland, France, } \\
\text { Spain, Italy }\end{array}$ & $\begin{array}{l}\text { United } \\
\text { Kingdom, } \\
\text { France, } \\
\text { Germany } \\
\end{array}$ \\
\hline Agriculture & $178,126.54^{\mathrm{b}}$ & $418,713.55^{\mathrm{c}}$ & $\begin{array}{l}\text { France, Spain, } \\
\text { United } \\
\text { Kingdom, } \\
\text { Germany }\end{array}$ & $\begin{array}{l}\text { France, } \\
\text { Germany, } \\
\text { Italy, Spain, } \\
\text { United } \\
\text { Kingdom } \\
\end{array}$ \\
\hline
\end{tabular}


Table 3 (continued)

\begin{tabular}{|c|c|c|c|c|}
\hline Sector & $\begin{array}{l}\text { Number of } \\
\text { firms }\end{array}$ & Turnover $^{\mathrm{a}}$ & $\begin{array}{l}\text { Largest } \\
\text { number of } \\
\text { firms }\end{array}$ & $\begin{array}{l}\text { Largest } \\
\text { turnover }\end{array}$ \\
\hline $\begin{array}{l}\text { Security and } \\
\text { investigation activities }\end{array}$ & 56,000 & $46,000.0$ & $\begin{array}{l}\text { France, United } \\
\text { Kingdom, } \\
\text { Hungary, } \\
\text { Germany }\end{array}$ & $\begin{array}{l}\text { United } \\
\text { Kingdom, } \\
\text { France, } \\
\text { Germany }\end{array}$ \\
\hline Mining and quarrying & 19,237 & $223,983.5$ & $\begin{array}{l}\text { Italy, } \\
\text { Germany, } \\
\text { Spain, France, } \\
\text { Poland, } \\
\text { Romania, } \\
\text { Portugal }\end{array}$ & $\begin{array}{l}\text { Norway, } \\
\text { Italy, United } \\
\text { Kingdom, } \\
\text { Netherlands }\end{array}$ \\
\hline $\begin{array}{l}\text { Architectural and } \\
\text { engineering activities; } \\
\text { technical testing and } \\
\text { analysis }\end{array}$ & $1,005,668$ & $329,000.0$ & $\begin{array}{l}\text { Italy, } \\
\text { Germany, } \\
\text { France, Spain, } \\
\text { United } \\
\text { Kingdom }\end{array}$ & $\begin{array}{l}\text { United } \\
\text { Kingdom, } \\
\text { Germany, } \\
\text { France }\end{array}$ \\
\hline Real estate activities & $1,369,456$ & $484,231.4$ & $\begin{array}{l}\text { Germany, } \\
\text { Italy, France, } \\
\text { Spain }\end{array}$ & $\begin{array}{l}\text { Germany, } \\
\text { France, } \\
\text { United } \\
\text { Kingdom }\end{array}$ \\
\hline
\end{tabular}

Source Eurostat

${ }^{\mathrm{a}}$ Millions €

${ }^{\mathrm{b}}$ Utilized agricultural area (thousands of hectares)

${ }^{\mathrm{c}}$ Output of the agricultural industry at basic prices (after taxes but including subsidies; million €)

\section{Main Competitors in the Sector}

Competitors in the drone sector operate globally, and this environment increases the rivalry in the market. To obtain a list of competitors in the industry, we used different lists obtained from sources specialized in the field (PwC 2016; Droneii 2016a) and a statistical database (Statista).

Through the analysis of the information on the web pages of the companies in these lists, including the products offered by the companies and their prices, we have organized the competitors using the same groups of markets as defined in Sect. 2. Therefore, we have established five groups of competitors depending on the market segment in which they sell their products (Tables 4, 5, 6, 7, 8):

- Group 1: manufacturers offering drones to consumer markets as toys,

- Group 2: manufacturers offering drones to consumer markets as hobby products,

- Group 3: manufacturers offering drones for professional purposes,

- Group 4: manufacturers offering drones for specific industries,

- Group 5: manufacturers offering military drones. 


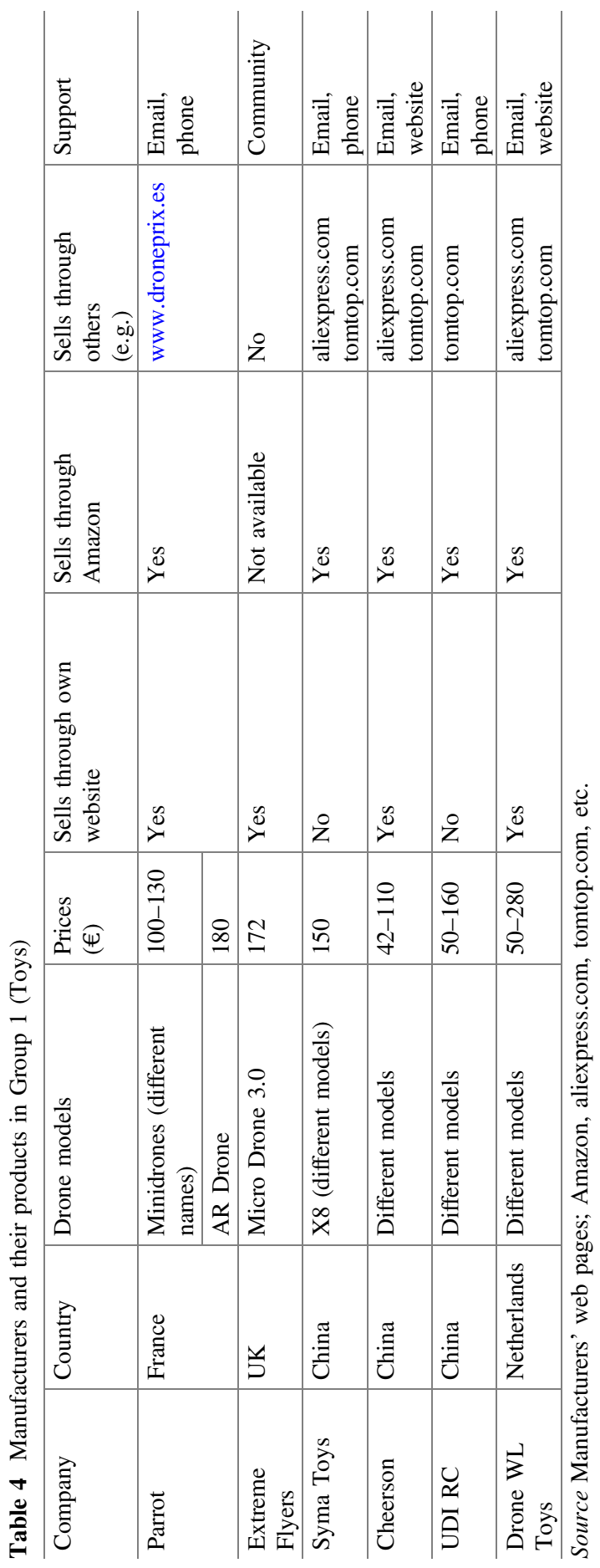




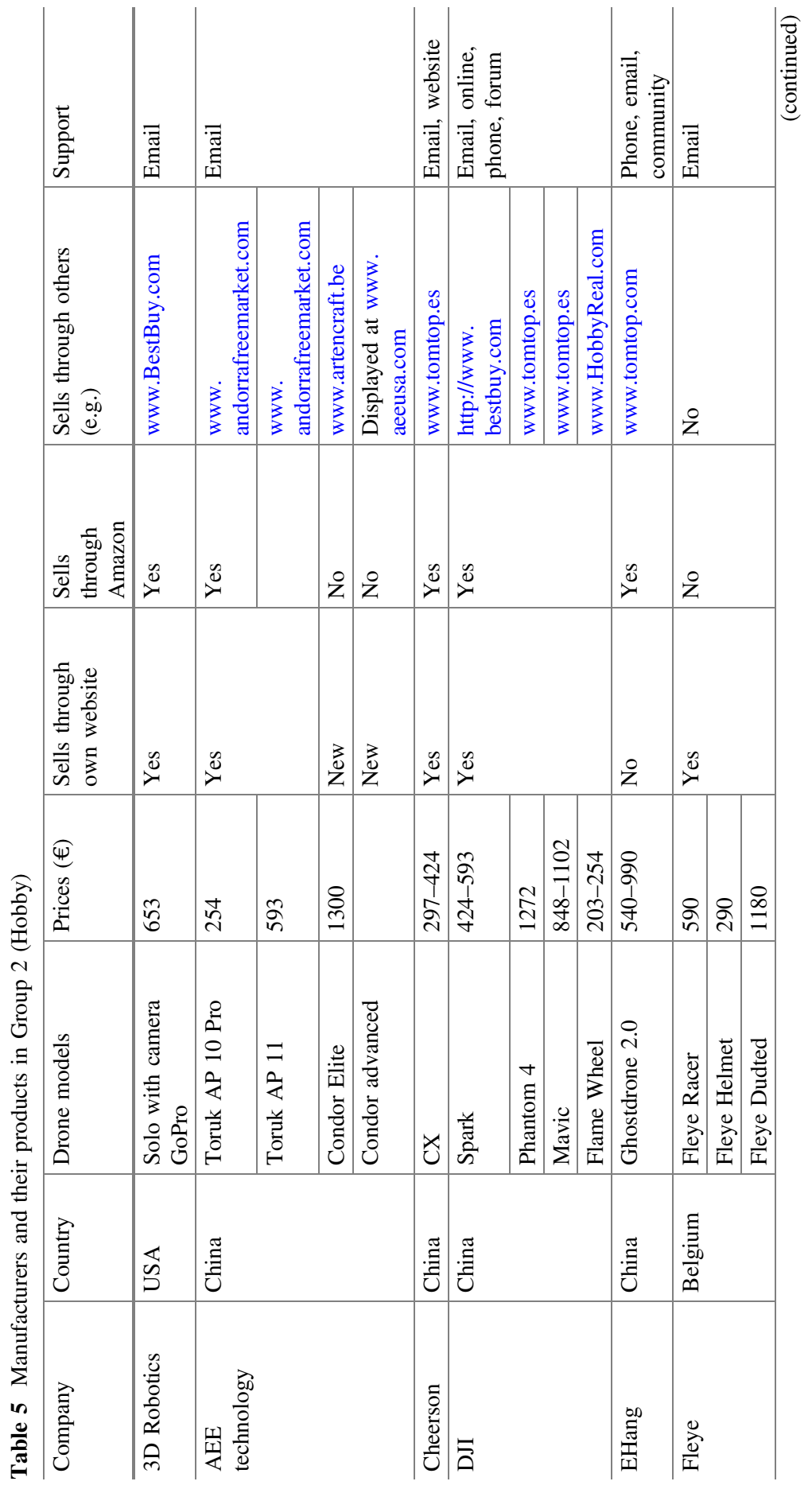




\begin{tabular}{|c|c|c|c|c|c|c|c|c|c|c|c|c|c|c|c|}
\hline 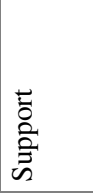 & $\begin{array}{l}\overline{\tilde{J}} \\
\overline{0} \\
\dot{0} \\
\tilde{\Xi} \\
\bar{D}\end{array}$ & 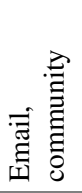 & 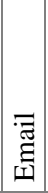 & 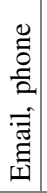 & $\begin{array}{l}\frac{0}{6} \\
\frac{0}{0} \\
\frac{0}{30} \\
3\end{array}$ & 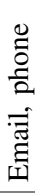 & 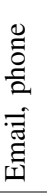 & & 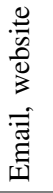 & 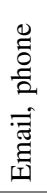 & 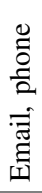 & & & & \\
\hline 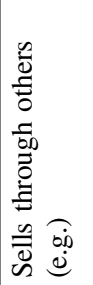 & 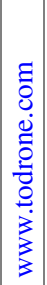 & 之o & 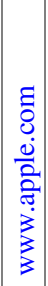 & 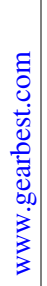 & $\stackrel{\circ}{z}$ & 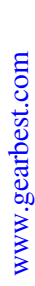 & 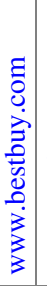 & 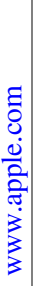 & 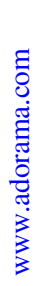 & 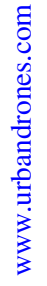 & 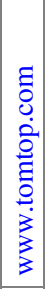 & 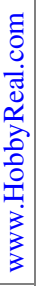 & 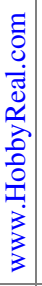 & 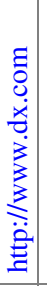 & 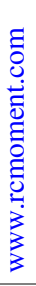 \\
\hline
\end{tabular}

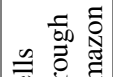

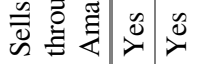

$そ)$

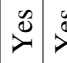

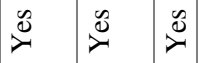

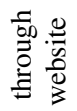

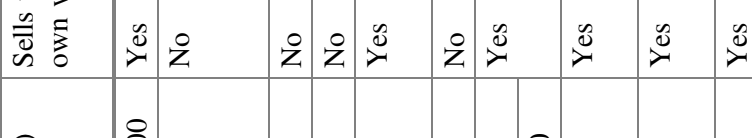

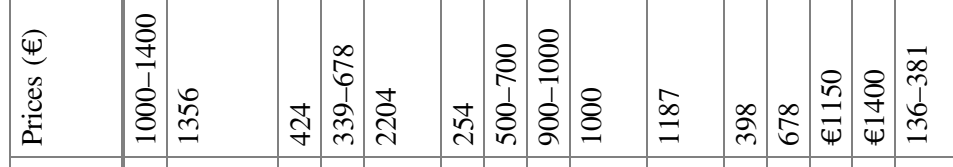

\begin{tabular}{|c|c|c|c|c|c|c|c|c|c|c|}
\hline 志 & 岕 & 㞼 & : & $\stackrel{\stackrel{\Xi}{\Xi}}{\stackrel{\Xi}{\Xi}}$ & 氐 & 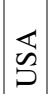 & 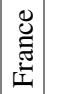 & 死 & 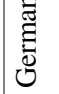 & 解 \\
\hline 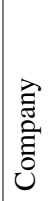 & $\begin{array}{l}\circ \\
0 \\
0 \\
0\end{array}$ & 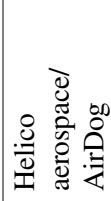 & 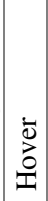 & 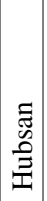 & 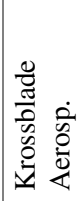 & 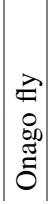 & : & 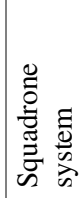 & 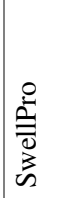 & 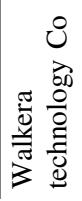 \\
\hline
\end{tabular}




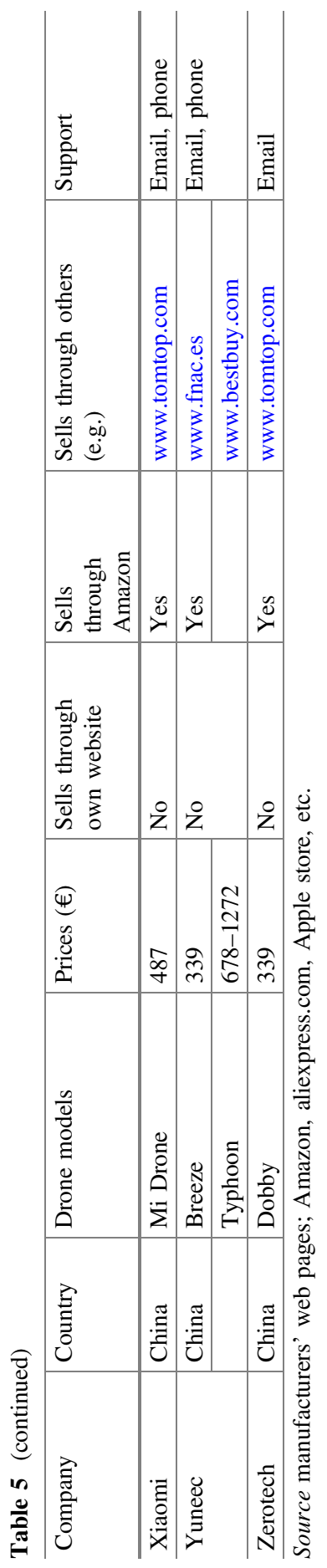




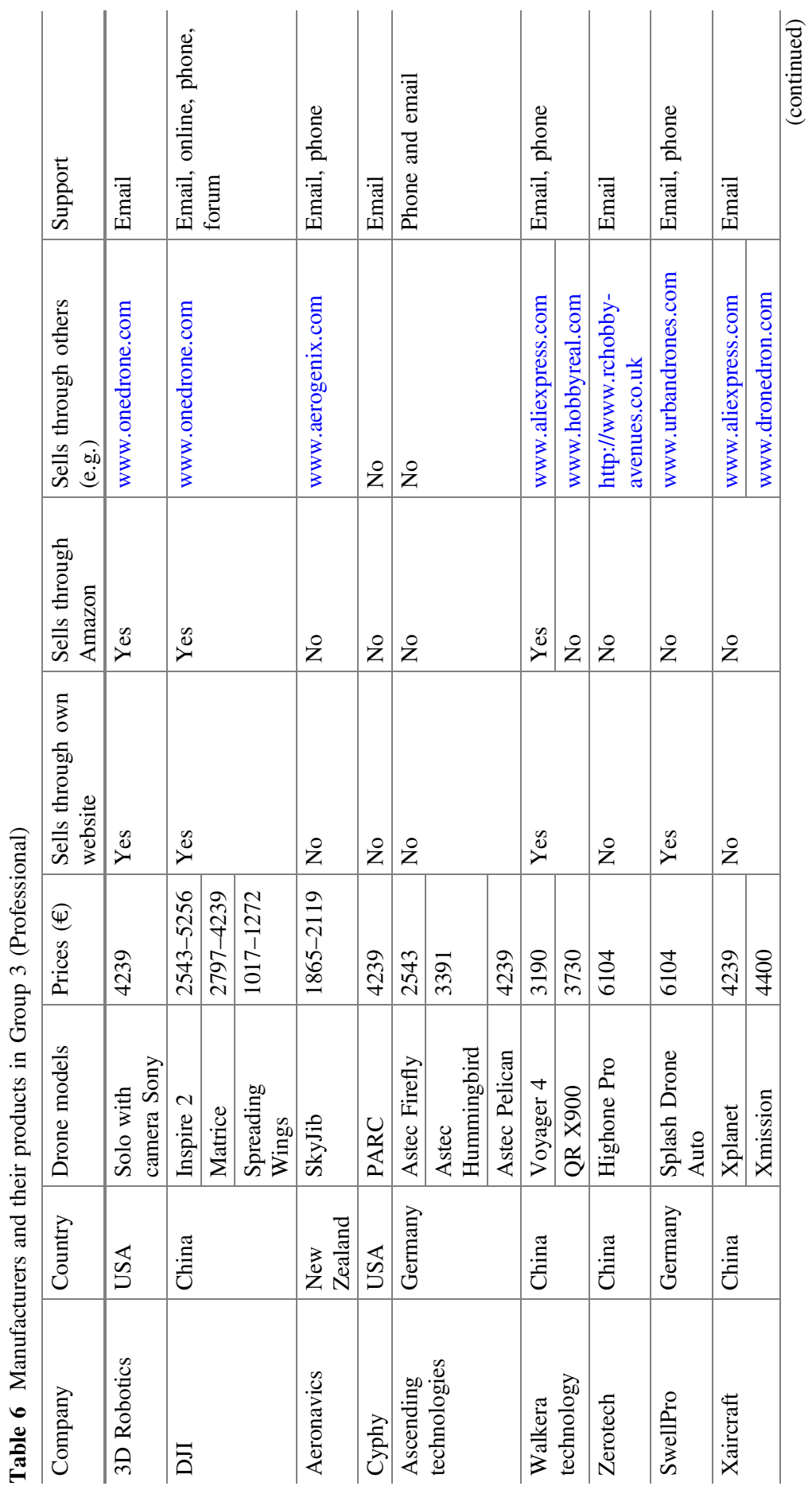




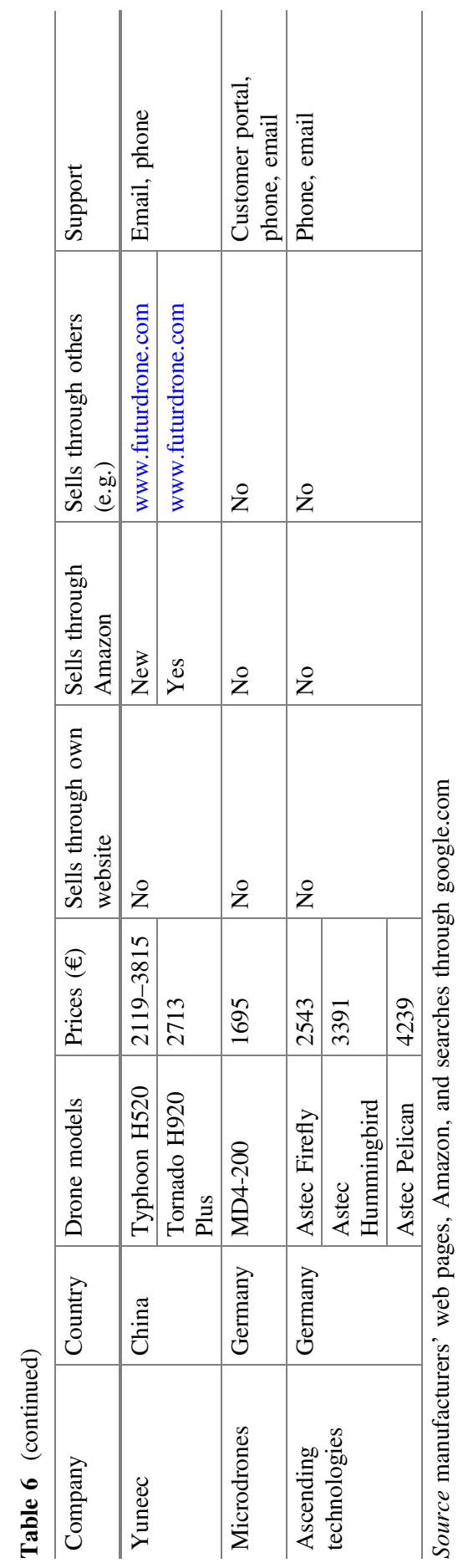




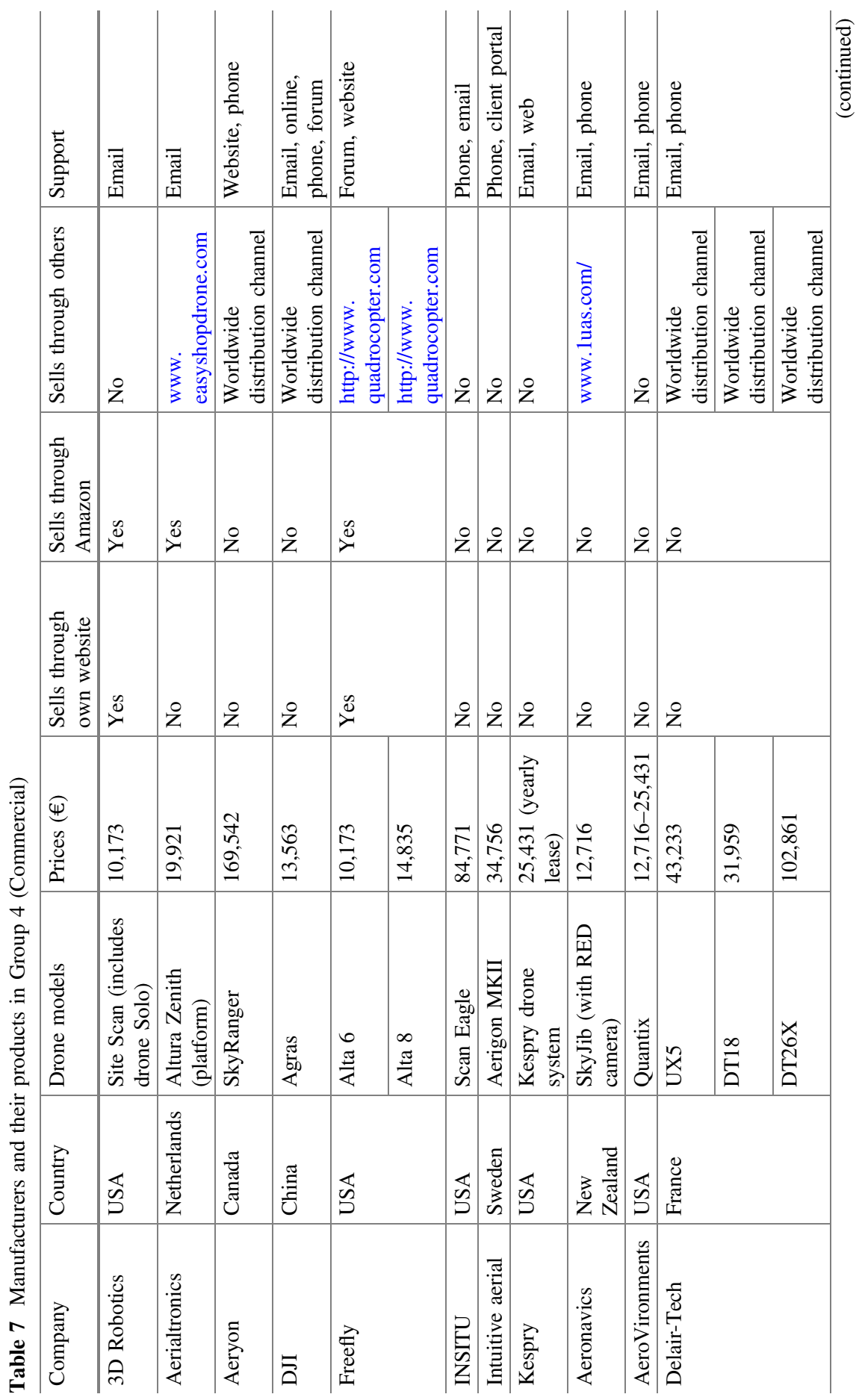




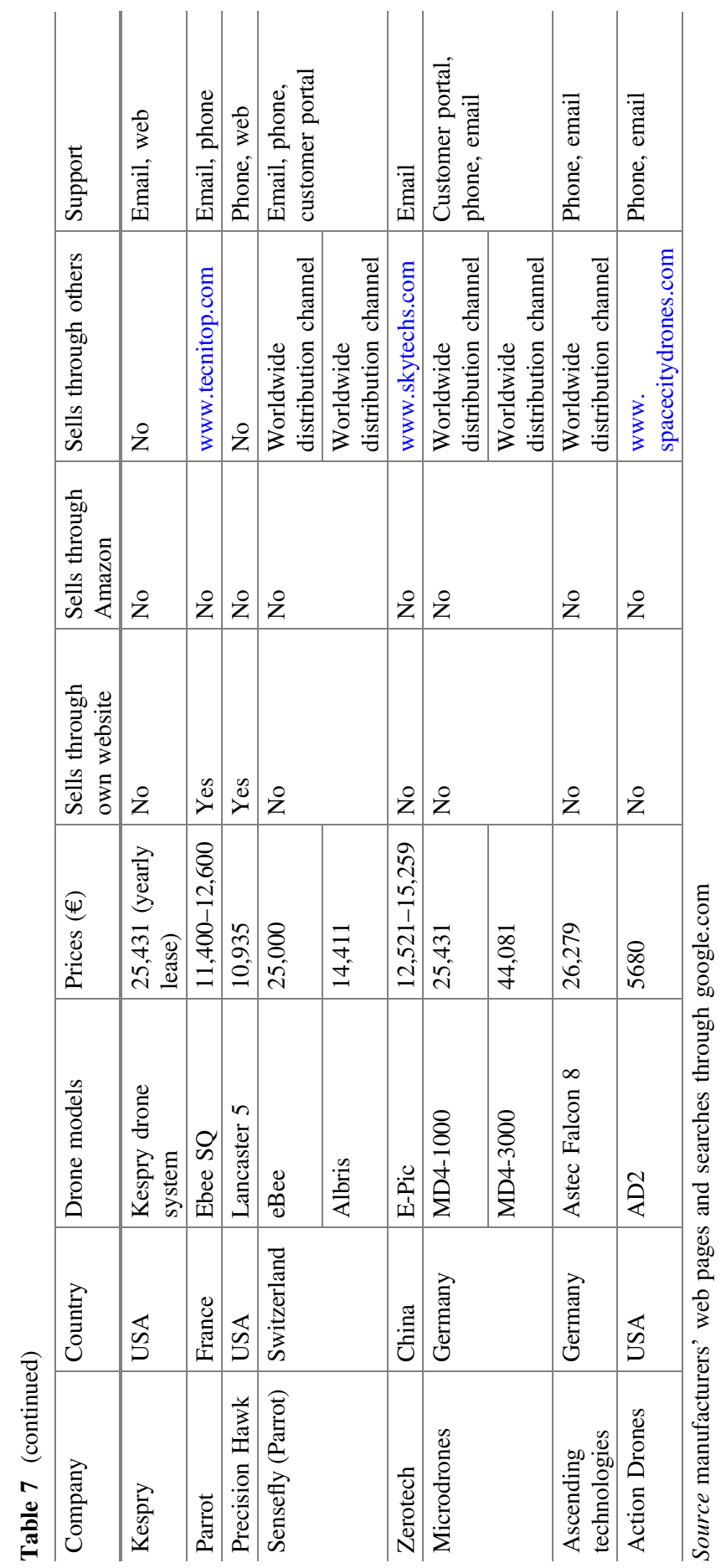


Group 1 (Toys) includes manufacturers of drones of which the customer target is children, who will have their first experience of flying drones. Table 4 presents some examples of the companies included in this group, indicating that the prices are around $€ 100$ and that some models carry a camera while others do not. Companies use external selling channels, such as Amazon, to reach their customers. European manufacturers in this group have to compete with Chinese firms.

Group 2 (Hobby) involves manufacturers of products that are focused on different customers from Group 1, who want to film themselves and their relatives and/ or friends while participating in action sports or other activities. Taking into account the higher purchase capacity of customers in this group, drones will include more technical features than those in Group 1. These features might include a camera and storage function (e.g. Micro-SD card or similar). These recreational customers are also looking for customizable and programmable features, ease of use, durability, and flight time. They are willing to pay between $€ 500$ and $€ 1500$ for drones included in Group 2, and they buy them directly from the manufacturer's website, through Amazon, and through other dealers, such as www.aliexpress.com or www. tomtop.com (Table 5). This group seems to be more profitable considering the number of companies involved in it. However, companies have to compete with an important rival, the Chinese firm DJI.

Group 3 (Professional) includes manufacturers of drones for professional filming and photography. Drone operators whose main activity is aerial filming services use these types of products, which are sometimes high models of those shown in Group 2. The prices are below €10,000, and DJI is an important rival. This company is very active in partnering with other firms for both hardware and software. Nowadays, DJI competes with firms that offer drones with cameras (Inspire 2, Phantom 4 Pro) and with those that offer drone platforms to carry different cameras (Matrice 600 Pro, Spreading Wings S1000 +). It is difficult for smaller companies to offer both products, so they need to choose between them. Offering a platform without a camera would allow customers to fit the drone with professional cameras, such as RED and Alexa, with a higher final cost for the user. These cameras are heavy and need bigger drones with the capacity to fly with a heavy camera.

Group 4 (Commercial) involves manufacturers that develop solutions for specific industries. The value of the offering is based more on the software and applications than on the drone itself. Companies partner (Droneii 2016b) with software firms (Airmap, Facebook), hardware firms (Intel, Leica Geosystems), and cameras makers (Sony) in an effort to increase the value associated with their products. As a result, the final price of the solution, which includes a drone, is higher. Moreover, some drone manufacturers offer the software with a yearly fee license (Kespry), following the rules from the software industry. Group 4 also includes companies that offer services through a drone instead of selling it. The company designs and assembles the drone, but its business model is built on offering services related to drones as its value proposition. Therefore, Group 4 includes companies offering only the product (drone and software), the product and services, and only services. 


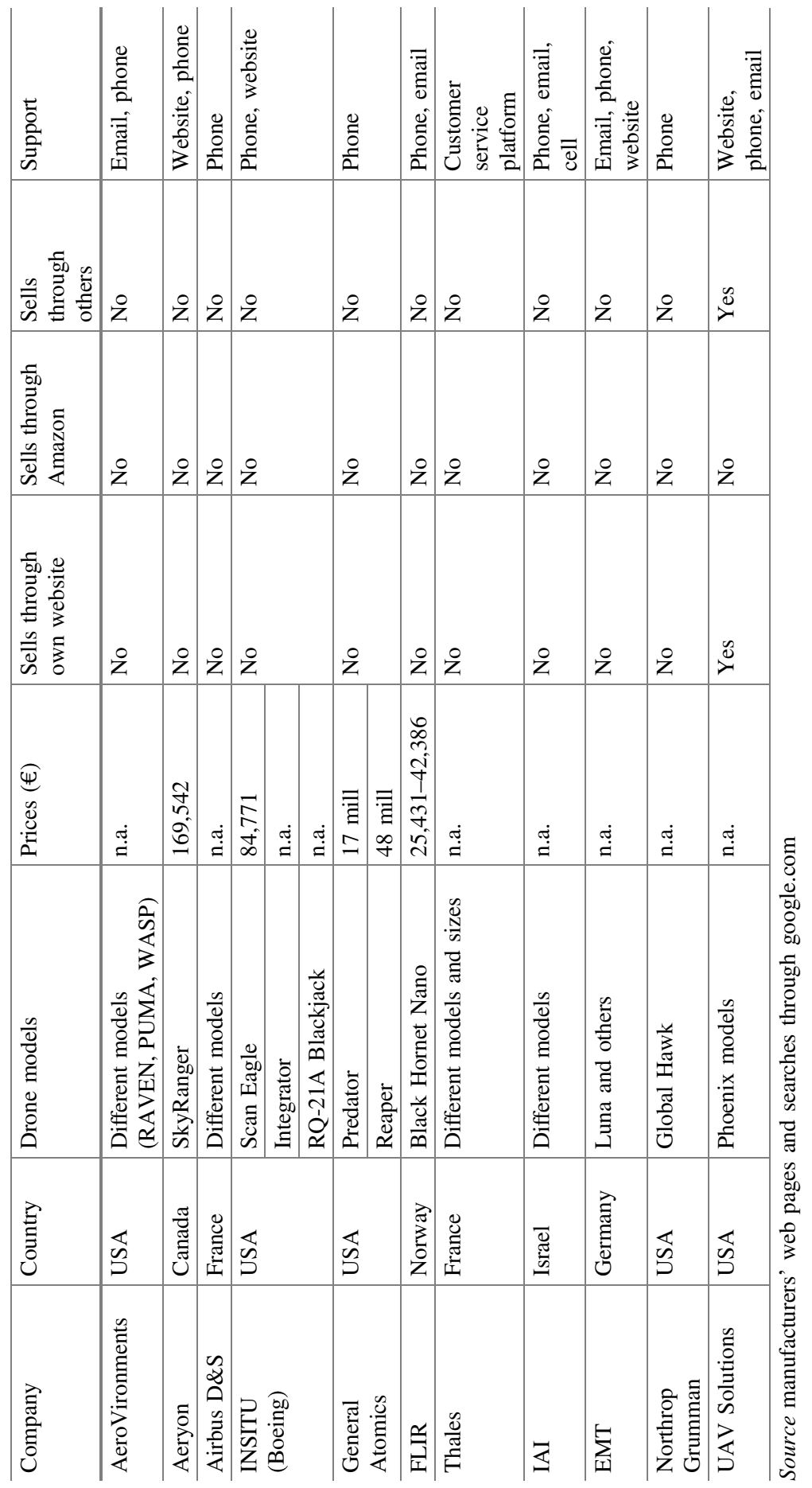


Few companies in Group 4 sell through their own online shop. Table 7 indicates that these companies are the ones with lower prices. The rest of the firms tend to sell directly to customers or use specialized dealers.

Group 5 (Military) includes manufacturers focused on defence and military purposes. They sell to armies, governments, and defence organizations like NATO (North Atlantic Treaty Organization). Companies need to fulfil the requirements specified by each government in security assurance relations. Some companies have started to offer products to customers in Group 4, as some of their products can be used for surveillance and monitoring. This might indicate their interest in the increase in the commercial market and the capacity of some of these industries to assume higher costs in buying drones and the services associated with them. Military companies have skilled resources and technologies that can be used for different purposes.

The software incorporated into drones has been demonstrated to be an importance source of value creation. This has produced parallel growth in companies focused on software development. Among these companies are Airware (USA), Dedrone (Germany), DroneDeploy (USA), MapBox (USA), PIX4D (Switzerland), RedBird (France), SkyWards (USA), and Skyworks Aerial System (USA). Most companies are from the United States and others are from European countries, outlining the drone industry. Some solutions allow the processing and analysis of data from images captured through drones, adapting their solutions to different industries (mining, agriculture, surveying, construction, etc.). Other companies work as developers of drone detection (Dedrone), flying simulators (Redbird), and platforms that publish data obtained through other drone software (MapBox).

The main conclusions that we could obtain from the analysis of the competitors are the following:

(a) As shown by the number of companies that enter the drone market every year, there are no high barriers to entry.

(b) Companies have started to extend their customer segments, especially the biggest companies in the sector. This can be observed in DJI, 3D Robotics, and Parrot, but also in some companies operating in both the commercial and the military segment.

(c) Camera makers and software developers are strategic partners for drone companies. For example, big companies use cameras and software to offer products with a higher value and adapt them to each segment. The final cost of the solutions will increase with these additional features. Increasingly these customers pay for the software included as an annual fee.

(d) New features spread rapidly through the industry (incremental innovations such as extended flight time, better cameras, less noise, auto charging batteries, etc.).

(e) The high number of competitors in the market might explain why they offer more than one selling channel for their products, although this is less usual for higher-priced drones (the military segment and some commercial solutions). 
(f) While companies are selling lower-priced drones online, higher-priced drones are usually sold directly after contact by email or through a worldwide distribution channel.

(g) The main support is obtained by users through channels including phone, email, and web pages.

(h) The price of military drones is not readily available and might depend strongly on the amount ordered, extra features, and the strategic point of view.

\section{Main European Figures}

Tractica's (2017b) data indicate that the revenue from commercial drones in Europe in 2015 was US\$99.53 million. Moreover, they estimate important growth in revenue from 2016 to 2025 . They forecast US $\$ 250.99$ million in revenues for 2018 , US\$1248.32 million for 2022, and US\$3035.33 million for 2025. Figure 5 presents these data in percentages, showing the highest growth period as 2018-2022. In terms of units, the current use of drones in Europe (SESAR 2016) is limited to around 1000 military drones, 1-1.5 million consumer drones, and 10,000 units of commercial drones. SESAR (2016) forecasts 200,000 units in 2025 and 395,000 in 2035 for the commercial domain, agriculture being the main domain with 150,000 units in 2035. Other important domains are energy (10,000 units), public safety and security (60,000), e-commerce and delivery (70,000), mobility and transport (1000), and others (media, mining and construction, insurance, real estate, telecommunication, and academic research) with 100,000 units in 2035. On the other hand, the main opportunities in the sector will be associated with service activities (related to software, data, and flying operations), which will absorb $80 \%$ of the total economic impact in 2035 (SESAR 2016).

Table 9 shows the location of drone companies in Europe and indicates that the main countries are the United Kingdom, Italy, Germany, and France. The importance of these countries is also clear when data about international trade and the number of operators registered are exposed. International trade data indicate that the country that imports the most drones is the United Kingdom, followed by India, Italy, Azerbaijan, Germany, Turkey, France, Singapore, and Brazil (The Guardian 2015a). On the other hand, the main exporting countries of drones are Israel, the United States, Canada, Russia, France, Austria, Italy, Germany, and China (The Guardian 2015b). Other sources include Spain and Switzerland among the important countries in the European drone market (Wichmann 2017). Tables 4, 5, 6, 7, 8 present the European manufacturers in each of the five segments analysed, and they included some of these countries. The leading European (Government Office for Science 2017) RPAS manufacturers are Parrot (France), AirRobot (Germany), Ascending Technologies (Germany), MicroDrones (Germany), UAV Factory (Latvia), and Aerialtronics (Netherlands).

Data about the number of drone operators certified are published by the aviation authorities of each country, although these data are not always available, because in 


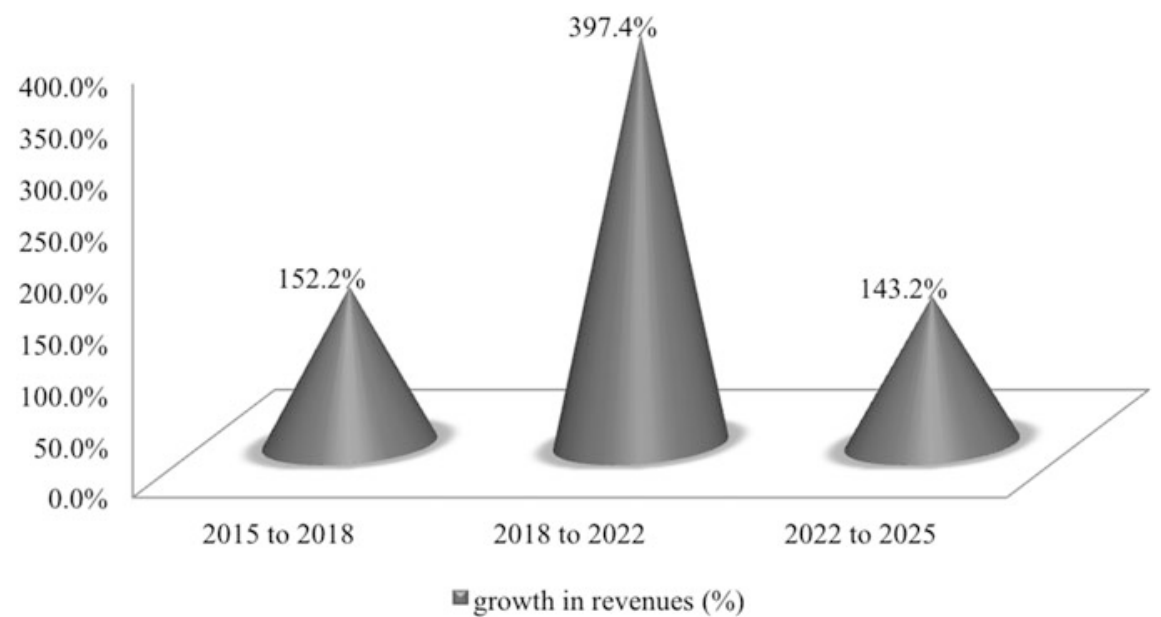

Fig. 5 Estimated growth in revenues for commercial drones in Europe. Source Own elaboration from data of Tractica (2017b)

Table 9 Drone manufacturers by European country in relation to important manufacturers' countries

\begin{tabular}{l|l|l|l}
\hline Country & $\begin{array}{l}\text { Number of } \\
\text { manufacturers }\end{array}$ & Country & $\begin{array}{l}\text { Number of } \\
\text { manufacturers }\end{array}$ \\
\hline USA & 229 & Israel, Spain & 16 \\
\hline China & 38 & Australia & 15 \\
\hline UK & 34 & $\begin{array}{l}\text { Austria, Netherlands, Sweden, } \\
\text { Switzerland }\end{array}$ & 8 \\
\hline Italy & 31 & Portugal, Romania, Slovenia, Ukraine & 4 \\
\hline Germany & 30 & $\begin{array}{l}\text { Belarus, Belgium, Bulgaria, Czech } \\
\text { Republic, Finland, Serbia }\end{array}$ & 3 \\
\hline France & 28 & Estonia, Hungary, Latvia & 2 \\
\hline $\begin{array}{l}\text { Canada, } \\
\text { Russia }\end{array}$ & 20 & Denmark, Greece, Ireland, Luxembourg & 1 \\
\hline
\end{tabular}

Source AUVSI (2016)

some countries, such as Germany, there is no registration of drone operators. Table 10 presents the number of licensed operators for some countries. This number has increased in the last years and is continuing to grow, indicating the attraction to this market of new professionals and companies. The activities carried out by these professionals and companies differ by country. For example, in Spain (Todrone 2016) the main activities using drones undertaken by companies and RPAS operators are audiovisual/leisure (45.8\%), infrastructure/mining (16.9\%), and agriculture/environment (14.5\%). In the United Kingdom (Government Office for Science 2017), however, the main activities are aerial photography/video, surveying/mapping, aerial cinematography, and industrial inspection. 
Table 10 Certified drone operators by country

\begin{tabular}{l|l|l}
\hline Country & Operators & Source \\
\hline United Kingdom & 3046 & Civil Aviation Authority (2017) \\
\hline Ireland & 172 & IAA (2017) \\
\hline France & 2250 & Statista (2016) \\
\hline Spain & 2420 & AESA (2017) \\
\hline Italy & 972 & ENAC (2017) \\
\hline Germany & n.a. & n.a. \\
\hline Switzerland & n.a. & n.a. \\
\hline Belgium & 152 & www.beuas.be/fr/membership/licentie \\
\hline
\end{tabular}

Source different sources (n.a.: not available)

\section{Conclusions}

In this chapter the available information regarding the drone industry has been compiled and analysed. Despite the sector having both technological and economic importance, there are important barriers preventing its expansion. The biggest barrier to the industry's development is regulation, which limits the use of drones based mainly on two different reasons: safety and security/privacy. Europe has to resolve this issue as quickly as possible, before the other two big economic countries, the USA and China, achieve advances that are too great compared with those of European firms, leading to an increased gap in academic, technological, business, and social development areas.

Although the first drones were produced in 1951 and the first document regarding unpiloted aircraft was patented in 1898, the main evolution of the drone industry has occurred in recent years, led mainly by military needs. Nowadays the most innovative drone uses can be associated with collaboration (health and drugs delivery, emergency surveillance, security, etc.) and commercial efficiency (agriculture, topography, etc.).

It is important to distinguish among the different segments within the drone industry, since the needs and characteristics of different end users are distinct and therefore the strategic considerations should be addressed separately. In this chapter five different segments have been identified:

- Toys, for which the final customers are children or young people and the use is educational.

- Hobby/leisure, for which the final customers are young people and adults for recreational uses.

- Professional, for which the final customers are drone pilots and the uses are aerial filming and photography services.

- Commercial, for which the final customers are companies and the uses are agriculture, media, mining, energy, or construction activities.

- Military purposes (vigilance, combat, etc.), for which governments are the end customers. 
These segments differ significantly. The price ranges vary widely as well as the basic drone characteristics, like drones with/without a camera, camera quality, flight stability requirements, flight time, data transmission, and so on, so the competitive analysis of the segments must be conducted separately.

Regarding the toy drone subsector, the price is the decisive feature, while quality and technology are not so important. In this segment European companies (mainly from France, UK and the Netherlands) coexist with Chinese ones, whereas North American ones are not represented. Chinese companies offer the cheapest drones (although the French company Parrot offers a minidrone for 30 euros) and have the widest distribution network (not only Amazon but also Aliexpress, which is the most recognized Chinese online seller). To sum up, the companies in this segment follow a cost-based strategy, and Chinese companies seem to have more options. Only by offering distinctive features (for example educational) or additional services (such as competitions for children and young people) can European companies play a role.

The second segment, which we called "hobby", seems to be more interesting for European companies, as quality, reliability, and technology play an important role in the final buying decision. The prices are higher (500-1000 euros); however, although they are important, the prices are not the primary aspect that final users consider when making their buying decision. Technology development (for example allowing the drone to follow you automatically when playing sport, associating with healthy applications, connecting to the usual devices, such as mobile phones or computers, to transfer data and images, and improving the safety measures) are the distinctive features that may define the best players in the near future. Chinese companies coexist with North American and European ones, with no clear leader. The distribution channels, technical support, and after-sales support are named as the key aspects, together with keeping in contact with the regulatory level to comply with safety regulations quickly and safely.

The "professional" segment is experiencing vibrant competition among the European, North American, and Chinese manufacturers. Although the market was led by European companies, the Chinese giant DJI is growing fast, along with other companies, such as Walkera, Zerotech, and Yuneec. The importance of pilot training courses, fair attendance, after-sales and technical support, and the software cost will define the subsector in the near future, together with filming/camera quality and ease of use. The regulations heavily constrain the final users, as they face the need for permits and licences and/or geographical restrictions in carrying out their work properly. The final price still differs by $30-40 \%$, but, as the final characteristics are not especially different, this subsector will tend towards homogenization unless clear quality/technological/service characteristics appear.

The commercial segment has a bright future and is currently the most interesting segment in which to compete. The final prices of drones are high, and the regulations do not particularly affect the final uses, as the main activities are carried out in rural areas or in emergency situations. Most of these drones can be adapted to the final use and associated services, as software and support add value to the final product. European and North American companies are definitely the leaders in this group. 
Information regarding the military segment, especially price and distinctive features, is not easy to find. No Chinese company is competing in this segment, and North American and European companies are mainly leading the segment development. The regulations do not affect the development of this segment as heavily, as the defence and civil fields differ in their limits and possibilities. These companies are often targeted directly by governments due to information restrictions, assuring, on one hand, the technological development and, on the other hand, strategic defence and information upgrades.

The easy of entry into the industry and the expansion of the biggest manufacturers, DJI especially, to other segments, is an important threat for companies operating in segments such as professional and commercial. Moreover, this big firm enters the segment with lower prices, forcing the existing companies to reduce their own prices. Companies are also responding to this threat with a value increase of their products, based on their associated software, which has been developed for specific industries (agriculture, mining, etc.). As a consequence, products have become solutions and cooperation between drone manufacturers and software firms has been the trend during the last years. Military companies have also been attracted to the commercial segment, taking advantage of its advanced technology, which can be used in industries other than defence. Despite positive forecasts for the commercial segment in the next two decades, an increase in rivalry might reduce the profitability in the medium term due to the life cycle of the technologies incorporated into the products. Companies will need to adapt their solutions constantly and take care of their customers by supporting them in purchasing, use, and maintenance.

The main difficulty that we faced during the elaboration of this chapter was the lack of statistics related to this sector. The registration of drone operators, including the drones to be operated, would increase the information available for companies, policy makers, and researchers.

\section{References}

Agencia Estatal de Seguridad Aérea (AESA) (2017) Registro de declaración responsable de operador de aeronaves RPA's. www.seguridadaerea.gob.es/lang_castellano/cias_empresas/ trabajos/rpas/default.aspx. Accessed 22 July 2017

Amukele T, Ness PM, Tobian AAR, Boyd J, Street J (2017) Drone transportation of blood products. Transfus Pract 57:582-588

AUVSI (2016) Maker melting point. Unmanned Syst 34(4):14-15

Casella E, Collin A, Harris D, Ferse S, Bejarano S, Parravicini V, Hench JL, Rovere A (2017) Mapping coral reefs using consumer-grade drones and structure from motion photogrammetry techniques. Coral Reefs 36:269-275

Chabot D, Francis CM (2016) Computer automated bird detection and counts in high-resolution aerial images: a review. J Field Ornithol, 87(4):343-359

Chowdhury S, Emelogu A, Marufuzzaman M, Nurre SG, Bian K (2017) Drones for disaster response and relief operations: a continuous approximation model. Int $\mathrm{J}$ Prod Econ $188: 167-184$ 
Civil Aviation Authority (CAA) (2017) Small Unmanned Aircraft (SUA) operators holding a valid CAA permission. http://publicapps.caa.co.uk/docs/33/20170714RptUAVcurrent.pdf. Accessed 21 July 2017

Droneii (2016a) Top 20 drone company ranking Q2 2016, activity and global reach of the Top20 leading hard- and software manufacturer in the drone industry. www.droneii.com. Accessed 19 July 2017

Droneii (2016b) Drone company partnership. https://www.droneii.com/drone-company-partnerships. Accessed 19 July 2017

ENAC (2017) Operatori autorizzati. www.enac.gov.it/La_Regolazione_per_la_Sicurezza/Sistemi_ Aeromobili_a_Pilotaggio_Remoto_\%28Droni\%29/Operatori_SAPR/index.html. Accessed 22 July 2017

Government Office for Science (2017) The UK value stream for remotely piloted civil aircraft systems (RPAS). www.gov.uk/government/publications/value-of-drones-to-the-uk-literaturereview. Accessed 22 July 2017

Hardy A, Makame M, Cross D, Majambere S, Msellem M (2017) Using low-cost drones to map malaria vector habitats. Parasites \& Vectors 10:29

Hodgson A, Peel D, Kelly N (2017) Unmanned aerial vehicles for surveying marine fauna: assessing detection probability. Ecol Appl 27(4):1253-1267

IAA (2017) Drone operators contact list. https://www.iaa.ie/general-aviation/drones/rpas-aerialwork-permission-holders. Accessed 21 July 2017

Infographic (2016) How tesla developed the first drone ever. https://patentyogi.com/nikola-tesla/ tesla-developed-first-drone/. Accessed 17 July 2017

Moe M, Pampoulov L, Jiang L, Franco N, Han S (2016) Eye in the sky. Available via Statista, the statistics portal. www.a2apple.com/eye-in-the-sky/ and https://es.statista.com/estadisticas/ 660906/prevision-del-valor-mundial-de-los-segmentos-de-mercado-de-drones/. Accessed 17 July 2017

Narkus-Kramer M (2017) Future demand and benefits for small unmanned aerial systems (UAS) package delivery. In: 17th AIAA aviation technology, integration, and operations conference, AIAA AVIATION Forum (AIAA 2017-4103)

Ott I (2012) Service robotics: an emergent technology field at the interface between industry and services. Poiesis \& Prax 9(3-4):219-229

Pauner C, Kamara I, Viguri J (2015) Drones. Current challenges and standardisation solutions in the field of privacy and data protection. ITU Kaleidosc: Trust in the Inf Soc (K-2015):1-7

Pulver A, Wei R, Mann C (2016) Locating AED enabled medical drones to enhance cardiac arrest response times. Prehospital Emerg Care 20(3):378-389

PwC (2016) Clarity from above. PwC global report on the commercial applications of drone technology. https://www.pwc.pl/pl/pdf/clarity-from-above-pwc.pdf. Accessed 29 June 2017

Restas A (2015) Drone applications for supporting disaster management. World J Eng Technol 3 (3):316

San Diego Air and Space Museum (2017) http://sandiegoairandspace.org/hall-of-fame/honoree/t.claude-ryan. Accessed 17 July 2017

Sankey T, Donager J, McVay J, Sankey JB (2017) UAV lidar and hyperspectral fusion for forest monitoring in the southwestern USA. Remote Sens Environ 195:30-43

SESAR Joint Undertaking (2016) European drones outlook study. Unlocking the value for Europe. www.sesarju.eu/sites/default/files/documents/reports/European_Drones_Outlook_Study_2016. pdf. Accessed 19 July 2017

Smith WR (1956) Product differentiation and market segmentation as alternative marketing strategies. J Mark 21(1):3-8

Statista (2016) Nombre d'opérateurs commerciaux de drones déclarés en Australie, au Royaume-Uni, en France et aux États-Unis en février 2016. https://fr.statista.com/statistiques/ 638340/operateurs-commerciaux-enregistres-monde/. Accessed 5 July 2017

Szantol Z, Smith SE, Strona G, Koh LP, Wich SA (2017) Mapping orang-utan habitat and agricultural areas using Landsat OLI imagery augmented with unmanned aircraft system aerial photography. Int J Remote Sens 30(8/10):2231-2245 
Teal Group (2013) Estimated worldwide production value for unmanned aerial vehicles (military drones) from 2013 to 2022 (in million U.S. dollars). Available via Statista, the statistics portal. www.statista.com/statistics/428935/global-production-value-forecast-for-unmanned-aerial-systemsor-drones/. Accessed 5 July 2017

The Guardian (2015a) Major unmanned aerial vehicle (drone) importing countries between 2010 and 2014, by market share. Available via Statista, the statistics portal. www.statista.com/ statistics/429100/major-importing-countries-of-drones/. Accessed 5 July 2017

The Guardian (2015b) Major unmanned aerial vehicle (drone) exporting countries between 2010 and 2014, by market share. Available via Statista, the statistics portal. www.statista.com/ statistics/429171/major-exporting-countries-of-drones/. Accessed 5 July 2017

Todrone (2016) 1er barómetro del sector de los drones en España. www.todrone.com/wp-content/ uploads/pdf/Informe-Barometro-todrone-baja.pdf. Accessed 22 July 201721

Tractica (2016) Global consumer drones revenue from 2015 to 2021 (in million U.S. dollars). Available via Statista, the statistics portal. www.statista.com/statistics/608931/consumerdrone-revenue-worldwide/. Accessed 5 July 2017

Tractica (2017a) Projected commercial drone revenue worldwide from 2015 to 2025 (in million U. S. dollars). Available via Statista, the statistics portal. www.statista.com/statistics/607922/ commercial-drone-market-revenue-worldwide-projection/. Accessed 5 July 2017

Tractica (2017b) Projected commercial drone revenue in Europe from 2015 to 2025 (in million U. S. dollars). Available via Statista, the statistics portal. www.statista.com/statistics/607794/ commercial-drone-market-revenue-in-europe-projection/. Accessed 5 July 2017

Tractica (2017c) Drones for commercial application. Available via Statista, the statistics portal. www.statista.com/statistics/607897/commercial-drone-market-revenues-in-middle-east-andafrica-projection/; www.statista.com/statistics/607794/commercial-drone-market-revenue-ineurope-projection/; www.statista.com/statistics/607872/commercial-drone-market-revenue-inlatin-america-projection/; www.statista.com/statistics/607769/commercial-drone-market-revenuein-north-america-projection/; www.statista.com/statistics/607808/projection-of-the-commercialdrone-market-revenue-in-asia-pacific/. Accessed 17 July 2017

Venter P, Wright A, Dibb S (2015) Performing market segmentation: a performative perspective. J Mark Manag 31(1-2):62-83

Wichmann T (2017) Expanding drone operations into Europe. Available via Skyward. https:// skyward.io/expanding-commercial-drone-operations-into-europe/. Accessed 21 July 2017

Wind Y (1978) Issues and advances in segmentation research. J Mark Res 15(3):317-337

Open Access This chapter is licensed under the terms of the Creative Commons Attribution 4.0 International License (http://creativecommons.org/licenses/by/4.0/), which permits use, sharing, adaptation, distribution and reproduction in any medium or format, as long as you give appropriate credit to the original author(s) and the source, provide a link to the Creative Commons license and indicate if changes were made.

The images or other third party material in this chapter are included in the chapter's Creative Commons license, unless indicated otherwise in a credit line to the material. If material is not included in the chapter's Creative Commons license and your intended use is not permitted by statutory regulation or exceeds the permitted use, you will need to obtain permission directly from the copyright holder.

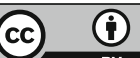

